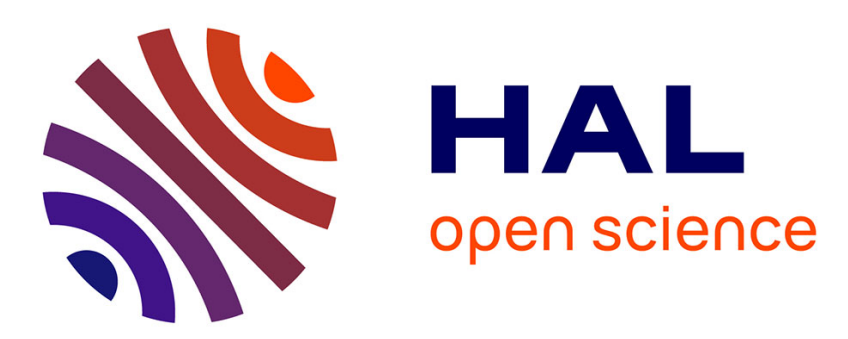

\title{
Refractory Coatings of C-Me-Si and C-Me-B-Si Systems for Protection of Carbon Materials (CM)
}

S. Andryushin, A. Kasatkin

\section{To cite this version:}

S. Andryushin, A. Kasatkin. Refractory Coatings of C-Me-Si and C-Me-B-Si Systems for Protection of Carbon Materials (CM). Journal de Physique IV Proceedings, 1995, 05 (C5), pp.C5-815-C5-822. 10.1051/jphyscol:1995597. jpa-00253960

\section{HAL Id: jpa-00253960 https://hal.science/jpa-00253960}

Submitted on 1 Jan 1995

HAL is a multi-disciplinary open access archive for the deposit and dissemination of scientific research documents, whether they are published or not. The documents may come from teaching and research institutions in France or abroad, or from public or private research centers.
L'archive ouverte pluridisciplinaire HAL, est destinée au dépôt et à la diffusion de documents scientifiques de niveau recherche, publiés ou non, émanant des établissements d'enseignement et de recherche français ou étrangers, des laboratoires publics ou privés. 
JOURNAL DE PHYSIQUE IV

Colloque C5, supplément au Journal de Physique II, Volume 5, juin 1995

\title{
Refractory Coatings of C-Me-Si and C-Me-B-Si Systems for Protection of Carbon Materials (CM)
}

S.G. Andryushin and A.V. Kasatkin

Institute of Physical Chemistry, Academy of Science of the Russia, Leninsky pr. 31,117915 Moscow, Russia

\begin{abstract}
The three-zoned structure of the coatings for protection from high-temperature oxidation of carbon materials (CM) was grounded. The kinetic of formation and phase composition of diffusion coating $\mathrm{C}-\mathrm{Me}-\mathrm{Si}$ and $\mathrm{C}-\mathrm{Me}-\mathrm{B}-\mathrm{Si} \quad\left(\mathrm{M}_{e}=\mathrm{Ti}, \mathrm{Zr}\right.$ or $\left.\mathrm{Hf}\right)$ systems formed on CM (graphite and carbon/carbon materials) have been studied. The coating on CM received by using sequential metallization, boron- and silicium- deposition from dispersive solid-phased media. The rate of formation coatings of $\mathrm{C}-\mathrm{Me}-\mathrm{Si}$ by metallization and Si-deposition on CM decreases on the line: $\mathrm{Ti}-\mathrm{Zr}-\mathrm{-Hf}$, and the formation carbide layers MeC by diffusion metallization CM describes linear-parabolic law have been shown. The velocity of boron diffusion of the "CM - MeC layer" compositions is very little and it is increased on the line: $\mathrm{Ti}-\mathrm{Zr}-\mathrm{Hf}$ insignificantly. The formation of $\mathrm{MeB}_{2}$ layer at the boriding are decreased of the velocity of siliciding. The coating proposed hase three-zoned structure formed by compounds of $\mathrm{C}-\mathrm{Me}-\mathrm{Si}$ or $\mathrm{C}-\mathrm{Me}-\mathrm{B}-\mathrm{Si}$ systems and intended for protection of $\mathrm{CM}$ from high-temperature oxidation $\left(\mathrm{T}>1400^{\circ} \mathrm{C}\right)$. The laws of phase form and destruction at high-temperature oxidation in air for these coatings are investigated.
\end{abstract}

\section{INTRODUCTION}

Analysis of literature data and results of our investigations shows that successful protection of carbon materials (graphite, C-C composites) from high-temperature oxidation can be realized only by means of complex protective coatings $[1,2,3]$. The ultimate part is played, according to our opinion, by the special structural composition and by the exact combination of the phase components in the coating.

Obviously, any coating on carbon materials (CM) is subjected under high-temperature oxidation to the two opposite diffusion streams: oxpdation - the oxygen atoms stream from the oxidized surface, and reduction - the carbon atoms stream from the carbon base. At this point, the most significant problems for oxidation protection of CM are: the 
possibility to minimize the thermodynamical activity of carbon in the areas of the coating subjected to oxidation, and the possibly maximum resistance to the oxygen atoms intruding the coating. To successfully solve these problems, the special zone construction of the coating is necessary, consisting of the main - protective - layer, plus two barrier layers: the "carbon" one on the CW/coating boundary and the "oxygen" one on the outer surface of the coating.

The present work investigates the laws of forming the heatresistant protective coatings of $\mathrm{C}-\mathrm{Me}-\mathrm{Si}$ and $\mathrm{C}-\mathrm{Me}-\mathrm{B}-\mathrm{Si}$ systems (where $\mathrm{Me}=\mathrm{Ti}$, $\mathrm{Zr}$ or $\mathrm{Hf}$ ) on $\mathrm{CM}$ surface, processed by sequential operations of metallization and siliconization of the carbon base. The main attention is paid to investigate the laws of carbon diffusion barrier layers (MeC and $\mathrm{MeC}-\mathrm{MeB}_{2}$ ) forming on $\mathrm{CM}$, and to studying the processes of phase forming during the consecutive siliconization.

\section{EXPERIMENTAL METHODS}

The investigations were carried out using $C M$ samples of unrestricted shapes made of annealed graphite with density of $1.6 \mathrm{~g} / \mathrm{cm}^{3}$ and of $\mathrm{C}-\mathrm{C}$ composites with laminated (2D) structure and apparent density of $1.0-1.15 \mathrm{~g} / \mathrm{cm}^{3}$.

Diffusion composition coatings of Me-C-Si (where Me $=\mathrm{Ti}$, Zr or Hf) system on CM were obtained by two-staged routine. The first stage was intended to obtain the diffusion layers of $\mathrm{TiC}, \mathrm{ZrC}$ and $\mathrm{HFC}$ carbides of 5 to $50 \mu \mathrm{m}$ thickness on $\mathrm{CM}$ by means of CVD/CGD from solid disperse materials ( $\mathrm{Ti}, \mathrm{Zr}$ or Hf chipped). The CVD was carried out with halogenide activation, powdered fluorides $\left(\mathrm{MgF}_{2}, \mathrm{CaF}_{2}\right)$ being used. The processes were run in vacuo $(0.1-0.01 \mathrm{~Pa})$ at $1450-1500^{\circ} \mathrm{C}$. Further, on the second stage, diffusion siliconization of the obtained "CM - MeC layer" compositions was performed. The siliconization was carried out by tho methods: 1 - "low-temperature" - at $1300-1350^{\circ} \mathrm{C}$ in vacuo $0.01 \mathrm{~Pa}$ from powdered elemental Si burden; 2 - "high-temperature" - at 1450-1550 $\mathrm{C}$ in Si/SiC powder mixtures, taken in definite mass ratio with specially defined granule size composition.

Diffusion composite coatings of $\mathrm{C}-\mathrm{Me}-\mathrm{B}-\mathrm{Si}$ system (where Me = Ti, $\mathrm{Zr}$, or Hf) were obtained in hree stages. The corresponding diffusion carbide layers (MeC) on CM samples were preliminary formed, after that diffusion boronization of the obtained "CM - MeC" compositions was carried out. As the boron source powder mixtures of boron carbide $\left(\mathrm{B}_{4} \mathrm{C}\right)$ and amorphous boron were used, the process being performed in graphite containers at temperatures of $1300-1500^{\circ} \mathrm{C}$ in vacuo $(0.01 \mathrm{~Pa})$, during 2-3 hrs. For the finishing stage siliconization of graphite and $\mathrm{C}-\mathrm{C}$ composites samples with pre-deposed MeC-MeB2 layers was performed to form the composition protective coating of Me-C-B-Si system.

The phase and chemical compositions of the coatings, as well as their srtucture and elements distribution along the sross-section, were conrtolled on each stage using $X$-ray phase alalysis (DRON-2), metallography (MMP-4) and X-ray microspectral (Chemscan, Camebax) analysis. To investigate the kinetic laws of the coating-forming process, the weight method was used. 


\section{EXPERIMENTAL RESULTS AND THE DISCUSSION}

As a result of the conducted experiments, the dense diffusion composite coatings of Me-C-Si and Me-C-B-Si systems (where Me $=\mathrm{Ti}, \mathrm{Zr}$, Hf ) on CM (samples of graphite and $\mathrm{C}-\mathrm{C}$ composites) were obtained. The thickness varied from 40 up to $160 \mu \mathrm{m}$; the coatings of $60 \mu \mathrm{m}$ or thicker were formeded only at high-temperature siliconization heat treatment (above $1450^{\circ} \mathrm{C}$ ) in environment containing elemental Si.

\subsection{Coatings of the Me-C-Si system}

It is found out that to obtain qualitative diffusion carbide layers $(\mathrm{MeC})$ of up to $50 \mu \mathrm{m}$, and to provide an acceptable rate of their growth, the matallization processes (the first stage) must be conducted at temperatures of $1450-1500^{\circ} \mathrm{C}$, while titanization may be performed in a steam phase without use of activation. The layers of $\mathrm{ZrC}$ and $\mathrm{HfC}$ of thickness exceeding 10 um were obtained only by CVD method. with fluoride activator in the reaction zone.

$X$-ray phase analysis for layers of various thickness, obtained by titanization, zirconization or haffnization of $\mathrm{CM}$ at $1450-1500^{\circ} \mathrm{C}$ with various temporary endurance, has shown that they (for both graphite and $\mathrm{C}-\mathrm{C}$ composites samples) are presented by a single phase which was the corresponding carbide MeC, where Me - Ti, $\mathrm{Zr}$, Hf. We found out that, for the diffusion coatings of TiC on CM obtained by gaseous phase titanization, some reduction of concentration of carbon in the carbide layer's outer zone is observed, while its thickness increases (from TiCo.75 - for thin, < 10 um layers, up to TiCo.63 - for thick, $40-50 \mu \mathrm{m}$ layers), see fig. 1.

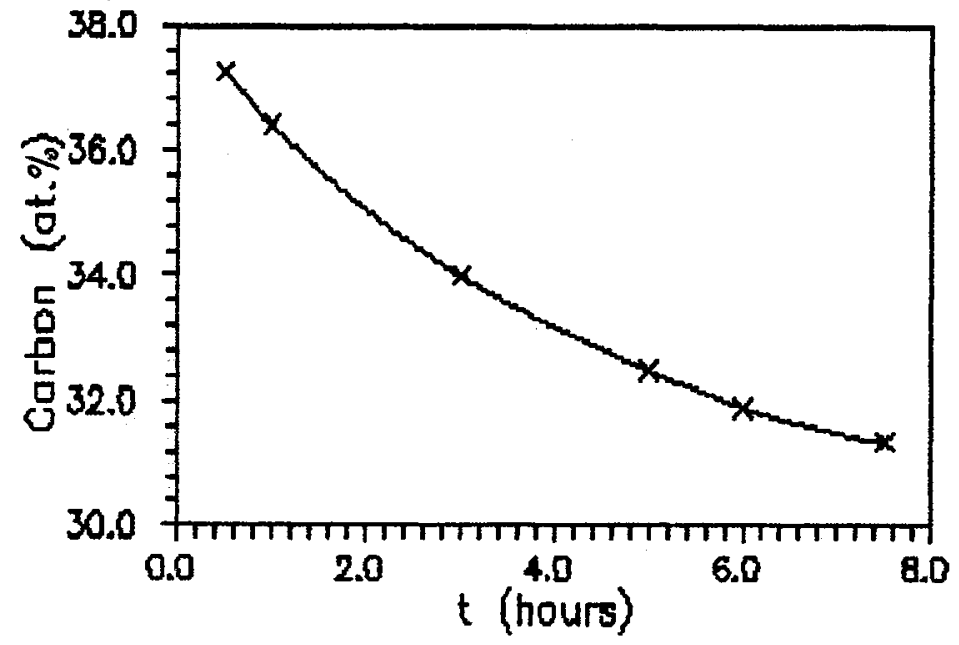

Fig.1: The dependence of carbon'concentration on the surface layer from exposition of titanization $\left(1450^{\circ} \mathrm{C}\right.$ ) for diffusion coatings (titanium carbide) on the CM. 
Some displacements of diffractional maxima (which fact testifies their non-stoichiometry) were found on X-ray spectra of zirconium and hafnium carbides layers, but in a considerably smaller degree, than for titanium carbide case. Besides that no dependence of their value on thickness of the coating was revealed. This distinction between the layers of $\mathrm{ZrC}$ and $\mathrm{HfC}$ on the one hand and $\mathrm{TiC}$ - on the other, can be explained, first, by that the homogenity areas of $\mathrm{ZrC}$ and $\mathrm{HfC}$ on the phase diagrams are essentially narrower, than for $\mathrm{TiC}$ [4], and secondly, by that zirconium and hafnium carbides layers were obtained with use of fluoride activation so the mechanics of their growth may differ from the case of $\mathrm{TiC}$ deposed from vapor phase. The last assumption is partly confirmed by results of researches for kinetics of forming the specified carbide layers (submitted on fig. 2).

It is found out that the speed of CGD of titanium carbide is 4-5 times higher, than for zirconium carbide (compare 1 and 2 on fig. 2), and the speed of CGD of hafnium carbide at $1450^{\circ} \mathrm{C}$ does not permit to obtain during 3-5 hours the continuous coatings HfC on CM. The form of curves 1 and 2 on fig. 2 shows that the dependence of thickness $(h)$ of the obtained carbide layer from the time ( $t$ ) at vapour-phase titanization is close to square-law: $H=a \times t^{n}$ (1), where $n=0.56-0.58$, and for vapour-phase zirconization this dependence has a linear form. The character of specified dependences testifies, that the main factor, limiting the speed of formation of titanium carbide on $C M$ in this case is diffusion of components through the growing layer of TiC (internal mass transfer), while the speed of $\mathrm{ZrC}$ and $\mathrm{HfC}$ growth is limited mainly by the low speed of evaporation of corresponding metals ( $\mathrm{Zr}$ and $\mathrm{Hf}$ ) at $1450^{\circ} \mathrm{C}$ (external mass transfer).

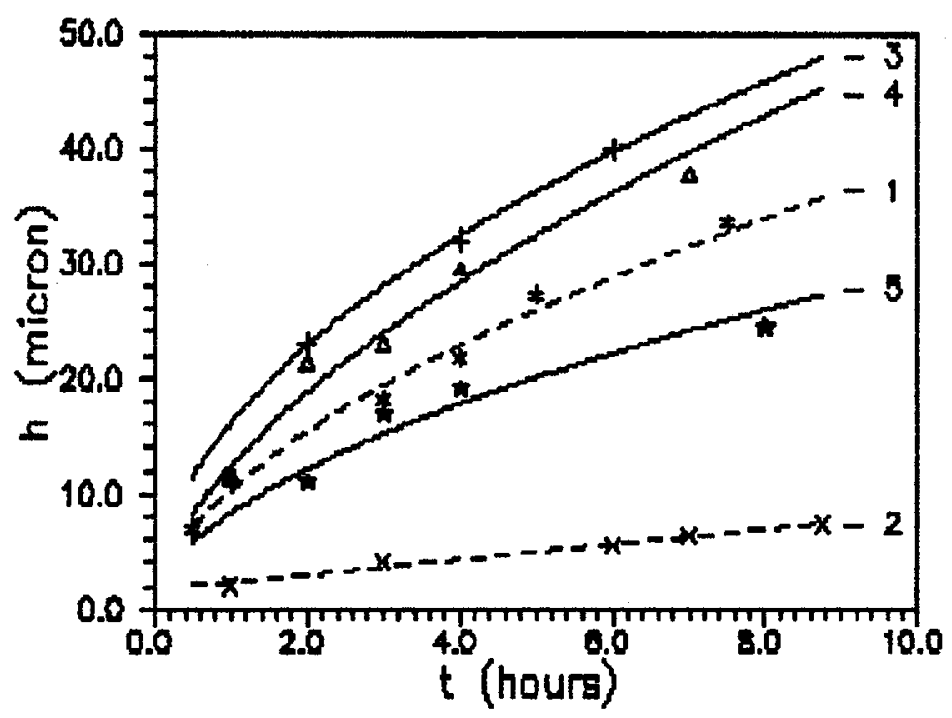

Fig.2: The kinetics of carbidization of the $\mathrm{CM}\left(1450^{\circ} \mathrm{C}, 0.01 \mathrm{~Pa}\right)$ : 1- TiC, 2- ZrC (vapor deposition); 3- TiC, 4- ZrC, 5- HfC (gasephaseous deposition). 
The gas phase method (with fluoride activation), used to form the specified carbides on CM, gives an increase of growth rate of the $\mathrm{ZrC}$ layers (and $\mathrm{HFC}$ ) by the factor of about 10, in comparison with vapour phase processes (see curve 4 and 2 on fig. 2). It is connected to formation of volatile fluorides of type MeF $x$ at interaction of the activator with a metal having partial pressure at $1450^{\circ} \mathrm{C}$ essentially higher, than the saturated vapour pressure of the appropriate metal. Thus the character of kinetic dependences varies from linear (curve 2 on fig. 2) to linear-parabolic (curve 4 and 5 on fig. 2), that testifies to shift of the growth mechanism for ZrC and HfC layers. Usage of fluoride activation to form $\mathrm{TiC}$ layers (the curve 3 on fig. 2) does not so essentially accelerates the process of growth, as it occurs for the case of $\mathrm{Zr}$ and $\mathrm{Hf}$ carbides. The TiC layer on $\mathrm{CM}$ in this case grows according to square-law dependence on time $(n=0.50-0.51$ in the equation (1)), so, probably, the speed of growth is limited only by internal mass transfer.

To obtain heat resisting composite coatings on CM of (MeC) - (MeSi; SiC) type, an investigation of processes of diffusion siliconization of CM with previously put barrier MeC layer was conducted.

It was established that, irrespective to conditions of siliconization, the phase structure of obtained coatings is presented by compounds of the corresponding Me-C-Si system. X-ray analysis always found out the phases of SiC, carbide and the major silicide of the corresponding metal. Besides that in some cases the coatings appear to contain some free silicon, plus reflexes which can concern to threefold compounds of MesSizC type or $\mathrm{Me}_{3} \mathrm{SiC}_{2}$, which are repotred to exist according to $[5,6]$.

So, for example, on low-temperature siliconization (up to $1350^{\circ} \mathrm{C}$ ) in silicon there were found on the surface of the obtained coatings phases as follow:

- for coatings of Ti-Si-C system: TiSiz, SiC, traces of TisSiz and, in some cases, free silicon;

- for coatings of Zr-Si-C system: ZrSiz, SiC plus lines being characteristic whether for solid solution of $\alpha-S i C-Z r C$, or for the threefold phase of $\mathrm{Zr}_{\mathrm{XSi}} \mathrm{Si}_{\mathrm{Z}}$;

- for coatings of $\mathrm{Hf}-\mathrm{C}-\mathrm{Si}$ system: HfSiz, $\mathrm{HfC}, \mathrm{SiC}$ and $\mathrm{Hf}_{2} \mathrm{Si}$.

On high-temperature siliconization $\left(1450-1550^{\circ} \mathrm{C}\right)$ in the mixes SiC+Si there were:

- for coatings of $\mathrm{Ti}-\mathrm{Si}-\mathrm{C}$ system: TiC, SiC, free $\mathrm{Si}$ and, in some cases, reflexes whether of $\mathrm{Ti}_{5} \mathrm{Si} 3$ or $\mathrm{Ti} 5 \mathrm{Si} 3 \mathrm{C}$;

- for coatings of Zr-Si-C system: SiC, ZrC, fre日 Si, in some cases solid solution of $\alpha$-SiC-ZrSi and threefold compounds (presumably); - for coatings of Hf-Si-C system: HfC, SiC, as well as reflexes corresponding to threefold phases or firm solutions.

General kinetic laws revealed for siliconization of CM with pre-layered $\mathrm{MeC}$ are the following. It is found out that the speed of "low-temperature" (below $1350^{\circ} \mathrm{C}$ ) siliconization from elementary silicon of graphite and $\mathrm{C}-\mathrm{C}$ composites samples with $\mathrm{TiC}$ sublayer is higher, than the speed of the similar process with use of diffusion $\mathrm{ZrC}-$ and HfC- sublayers of the same thickness. An illustration of that is fig. 3 . 


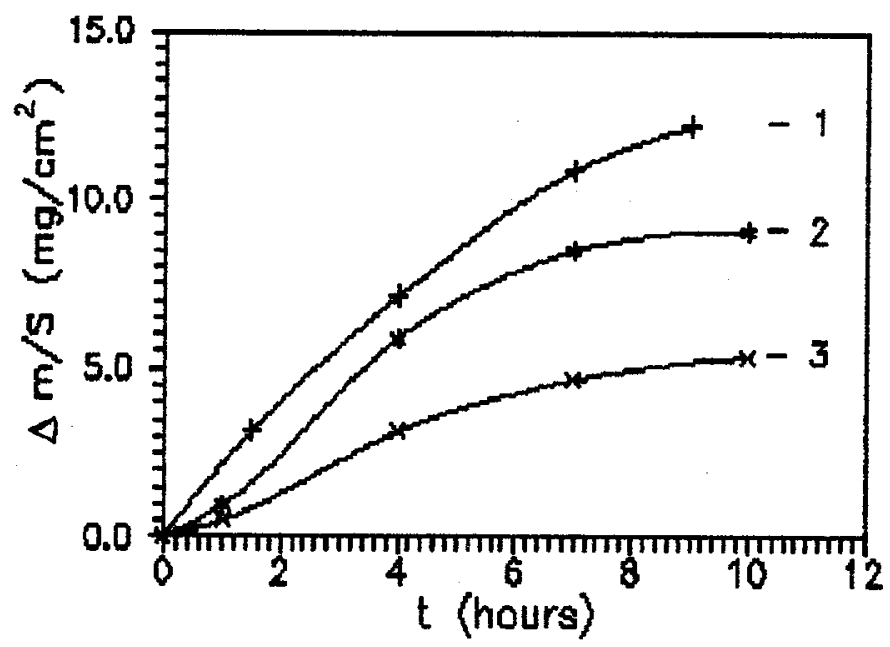

Fig.3 The kinetics of siliciding of grafite'carbidization (layer thikness - $15 \mu \mathrm{m})$ in $\mathrm{Si}$ powder, $\left(1330^{\circ} \mathrm{C}, 0.01 \mathrm{~Pa}\right): 1$ - TiC-layer, 2- 2rC-layer, 3 - HfC-layer.

This fact may be explained by two reasons: first, by existence of more fusible euthectics in $\mathrm{Ti}-\mathrm{Si}$ system rather than in $\mathrm{Zr}-\mathrm{Si}$ and $\mathrm{Hf}-\mathrm{Si}$ systems [7], and secondly, by greater presence of carbon defects in TiC layer due to its more wider area of homogenity than for ZrC and HfC. But both these reasons result in one consequence - higher diffusion mobility of silicon in a growing coating of $\mathrm{Ti}-\mathrm{C}-\mathrm{Si}$ system, rather than in coatings of $\mathrm{Zr}-\mathrm{C}-\mathrm{Si}$ and $\mathrm{Hf}-\mathrm{C}-\mathrm{Si}$ systems.

There was no strict correlation found between silicon absorption rate and the type of pre-layered on CM carbide layer at "high-temperature" (higher $1450^{\circ} \mathrm{C}$ ) siliconization in $\mathrm{SiC}+\mathrm{Si}$ mixes. However, the mentioned above tendency is being kept - the silicon absorption rate for siliconization of $\mathrm{CM}$ with $\mathrm{TiC}$ sublayer is a little higher than for $\mathrm{ZrC}$ and HfC. For high-temperature siliconization in SiC + Si mixes the process proceeds with participation of a liquid phase (since. T (sil.)> $>\mathrm{T}$ (fuz.) for $\mathrm{Si}$ ). This increases hugely the silicon absorption rate for account of intensification of internal and external mass transfer of coating components and results in shift of the mechanism of its growth, from pure vapour-phase at low-temperature siliconization to "vapour-liquid-solid" mechanism - at high temperatures, that is also confirmed by the changes of phase structure of the coatings (see above).

Metallography and X-ray microspectral researches data show that the structure of obtained coatings is rather complex and can be conditionally divided on three heterophaseuos zones. At the "carbon basis/coating" boundary a fine-dispersed mix of SiC and TiC phases in various ratio is located, further lies a zone of rough-dispersed mix containing, evidantly, TiC, TiSi (or $\mathrm{Ti}_{x} \mathrm{Si}_{y} \mathrm{C}_{z}$ ) and $\mathrm{SiC}$, then at last, closer to the surface - a zone of Tisiz and SiC enriched of free silicon. The similar picture can be observed for coatings of $\mathrm{Zr}(\mathrm{Hf})-\mathrm{Si}-\mathrm{C}$ system, with the only difference that the surface zone contains free silicon in a considerably smaller degree. 
Despite the complex character of elements distribution along the coating profile, general teridences of this distribution may be formulated as follows: the carbon contents in the coating from the base to the surface decreases practically down to zero; the silicon contents, in general, gradually grows from the base to the surface of the coating; the metal is distributed non-uniformly, basically being concentrated in the internal coating zones.

\subsection{Coatings of $\mathrm{H}_{0}-\mathrm{C}-\mathrm{B}-\mathrm{Si}$ system}

At the first stage of development of composite protective coatings of Me-C-B-Si system the problem of formation of diffusion barrier layer of $\left(\mathrm{MeC}-\mathrm{M}_{\ominus} \mathrm{B}_{2}\right)$ type on a CM surface was put forth.

Experiments showed that the diffusion boronization rate of $\mathrm{CM}-\mathrm{MeC}$ compositions (where Me - Ti, $\mathrm{Zr}$ or $\mathrm{Hf}$ ) at temperatures of $1300-1500^{\circ} \mathrm{C}$ is rather low. So the specific change of samples weight after boronization did not exceed $1.5-2.0 \mathrm{mg} / \mathrm{cm}^{2}$. The results of our researches show that there are two only phases formed on the samples surface after boronization: $\mathrm{MeC}$ and $\mathrm{MeB}_{2}$. In the coatings of Hf-C-B system, intensity of boride phase peaks ( $\mathrm{HfB}_{2}$ ) is essentially higher, than for carbide phase ( $\mathrm{HFC}$ ); for the $\mathrm{Zr}-\mathrm{C}-\mathrm{B}$ system various intensity ratio for reflections of $f$ the boride and carbide phases were revealed; and for the $\mathrm{Ti}-\mathrm{C}-\mathrm{B}$ system the appropriate to the carbide phase TiC reilexes, as a rule, were more intensive then reflexes appropriate to $\mathrm{T} i \mathrm{~B}_{2}$ phase.

The obtained data permit to assume that efficiency of boronization of CM with carbide sublayer (MeC) increases down the raw of $\mathrm{Ti}--\mathrm{Zr}--\mathrm{Hf}$.

Subsequent siliconization of $C M$ samples with diffusion layer $\left(\mathrm{MeC}-\mathrm{MeB}_{2}\right)$ on the surface was conducted under the same technological schemes as for siliconizing treatment of obtaining Me-C-Si coatings, however, the general picture of the phase composition and structure of the obtained coatings of Me-C-B-Si system is more complex, than for coatings obtained by siliconization of CM with MeC sublayer.

$X$-ray microspectral analysis finds out the presence of boron in external layers of the obtained composition coatings irrespective of the fact, which metal (Ti, $\mathrm{Zr}$ or Hf) was used to create the "barrier" diffusion $\mathrm{MeC}-\mathrm{MeB}_{2}$ layers. X-ray phase analysis has revealed that the main phase components on the surface of the obtained composition coatings are SiC and $\mathrm{MeB}_{2}$. Except above-stated phases on the surface of the obtained coatings, there are sometimes found whether solid solutions of MeSi-MeC or threefold phases of Me5SizC or Mes (Si;B) 3 type (in particular, it was fixed in coatings of the Ti-C-B-Si system).

It is found out also that siliconization of $C M$ with a previously formed MeC-MeB2 layer proceeds less intensively than for case of usage of appropriate carbide as intermediate sublayer.

It is necessary to note that replacement of carbide $(\mathrm{MeC})$ barrier diffusion layer for carbide-boride $\left(\mathrm{MeC}^{\mathrm{MeB}} 2\right)$ one did work to achieve some reduction of carbon concentration in surface layers of coating. 


\section{SOME LAWS ON PHASE FORMING AT HIEH-TEMPERATURE OXIDATION OF COATHNGS IN AIR}

We have conducted tests, concluded in heating of CM samples with coatings in atmosphere of static air, with the purpose to find out the laws on phase forming of oxide layers at high-temperature oxidation of the obtained coatings.

Samples of graphite with diffusion coatings of the C-Ti-Si system thick of $100 \mu \mathrm{m}$ (siliconizing treatment in $\mathrm{SiC}+\mathrm{Si} \operatorname{mix}$ at $1450^{\circ} \mathrm{C}$ ) were oxidized in air furnace with silicon carbide heater at $1400^{\circ} \mathrm{C}$ during 2 hours with thermocycling of mode: 15 minutes of isothermal endurance, 15 minutes of cooling outside of the furnace (total time of all the isothermal stages: 2 hours).

As a result, formation of glassed oxide film was observed on the coatings' surface. Specific gain in weight after oxidation has made no more than $0.1 \mathrm{mg} / \mathrm{cm}^{2}$. The method of X-ray phase analysis finds on oxidated coating surface the phase of $\alpha-\mathrm{SiO}_{2}$ crystobalite plus insignificant quantity (very weak reflections) of $\beta-\mathrm{TiO}_{2}$ (anataz). Besides that, reflexes appropriate to interjunction distances of SiC were fixed, that speaks about insignificant thickness of the oxide film or about an essential degree of its amorphization. Metallography analysis of cross-sections has revealed some presence of a non-uniform (in thickness) oxide film on the surface, the structure of coating not having undergone essential changes.

\section{Conclusions}

The conducted researches have shown the opportunity of formation of diffusion coatings of $\mathrm{C}-\mathrm{Me}-\mathrm{Si}$ and $\mathrm{C}-\mathrm{Me}-\mathrm{B}-\mathrm{Si}$ (where $\mathrm{Me}=\mathrm{Ti}, \mathrm{Zr}$ or $\mathrm{HF}$ ) systems on $\mathrm{CM}$, structured by the most favorable way for fulfilment the function of heat resisting protection. The presence of barrier layers $\mathrm{MeC}$ and $\mathrm{MeC}-\mathrm{MeB}_{2}$ on a boundary with the carbon base permits to lower essentially concentration of carbon in the surface layers of coatings, subjected to oxygen effect at high-temperature oxidation. The barrier properties of carbide layers is increased on line: TiC - ZrC - HfC. Mechanism of phase-forming for the siliconization (MeC-CM) was proposed.

\section{REFERENCES}

[1] Strife J.R., Mater.Speaking of Mater.Technol.Center, South.Illinois University at Carbondale 7, No 1(1990) pp.2-6.

[2] Kawai C. and Igarashi T., J.Ceram.Soc.Jap. 99, No5(1991) pp.390-394.

[3] Dallaire S., Surfase and Coating Technolgy 32 (1987) pp.141-152.

[4] Kiffer R., Benezovskii F., Tverdye materialy (Mettalurgiya, Moskva, 1968) pp. 42-72.

[5] Borisova A.L., Sovmestimost tugoplavkih soedinenii s metallami i grafitom (Naukova Dumka, Kiev, 1985).

[6] Lowden R.A. et al. Mat. Res. Soc. Symp. Proc. 168(1990) pp.159-165.

[7] Samsonov G.V. i dr. ,Silisidy (Metallurgiya,Moskva, 1979) pp.137-152. 